\title{
The effects of total quality management on customer service management in the Nigerian banking industry: an empirical analysis
}

\author{
Olawumi Dele Awolusi \\ Department of Business Administration and Marketing, \\ School of Postgraduate Studies, \\ Babcock University, \\ Ilishan-Remo, Ogun State, P.M.B 21244, \\ Ikeja, Lagos, Nigeria \\ E-mail: awosco44@yahoo.com
}

\begin{abstract}
This paper investigates the effectiveness of the critical success factors (CSFs) of total quality management (TQM) on customer service management (CSM) in the Nigerian banking industry. The empirical study was conducted via a survey on six, out of the 22 banks that have implemented TQM due to the 2004 consolidation exercise of the Central Bank of Nigeria (CBN). Using the Malcolm Baldrige National Quality Award (MBNQA) 2001 award framework, factors manifesting customer service management were regressed on the key factors manifesting successful TQM. The results posit that, for TQM to be successfully implemented, workers must be allowed to set goals and performance monitoring, effective communication, commitment and support from the top management, careful alignment of corporate strategy with TQM strategy, clear and compelling TQM vision, constant review of TQM implementations to align with plans and budgets, effective process review and controls, quality improvement measurement systems and IT infrastructures. The model provides predictive implications on improved CSM, given the activities of CSFs manifesting successful TQM. Hence, to improve CSM, banks could control their TQM programme.
\end{abstract}

Keywords: total quality management; TQM; customer service management; CSM; factor analysis; multivariate analysis; banking; Nigeria.

Reference to this paper should be made as follows: Awolusi, O.D. (2013) 'The effects of total quality management on customer service management in the Nigerian banking industry: an empirical analysis', Int. J. Management and Network Economics, Vol. 3, No. 1, pp.57-77.

Biographical notes: Olawumi Dele Awolusi is an alumnus of Nottingham University, UK. He is with the Department of Business Administration and Marketing, School of Postgraduate Studies, Babcock University, Ilishan-Remo, Ogun State, Nigeria. His main research interests are management technique adoption strategies, international business and strategies. Some of his recent publications can be found in the International Journal of Business Performance Management and the International Journal of Services and Operations Management. 


\section{Introduction}

Total quality management (TQM) is hailed as one of the current drivers of change within organisations, helping them to survive in the more competitive, customer-oriented commercial environment of today. Companies use TQM to improve performance substantially on key processes that impact customers and organisational performance. TQM can serve as a veritable tool for costs and cycle time's reduction, by eliminating unproductive activities and the employees who perform them (Davenport and Short, 1990). In addition, TQM improves quality by reducing the fragmentation of work and establishing clear ownership of processes, hence, workers gain responsibility for their output and can measure their performance based on prompt feedback (Mohrman et al., 1995; Partlow, 1996; Davenport and Short, 1990).

In addition, TQM is a strategic process of creating sustainable competitive advantage, if well implemented (Sila and Ebrahimpour, 2003; Crosby, 1979; Feigenbaum, 1951; Juran et al., 1974). In relation to other quality management techniques, Davenport and Short (1990) conclude that TQM and BPR share a cross-functional orientation. They observed that quality management, often referred to as TQM or continuous improvement refers to programmes and initiatives that emphasise incremental improvement in work processes and outputs over an open-ended period of time. In contrast, BPR, also known as business process redesign or process innovation, refers to discrete initiatives that are intended to achieve radically redesigned and improved work processes in a bounded time frame (Mohrman et al., 1995; Partlow, 1996; Davenport and Short, 1990).

Quality gurus such as Deming and Juran contend that quality management concepts are universally applicable, although a personal prescriptions, it must be examined empirically (Crosby, 1979; Juran et al., 1974; Sila and Ebrahimpour, 2003). In addition, the aftermatch of the 2004 consolidation exercise in the Nigerian banking industry has seen the implementation of TQM initiatives as a strategic imperative by many banks. Nevertheless, the effectiveness of TQM in this context has hitherto not been investigated. In other word, the importance of quality management has now become very important in the Nigerian banking industry. As noted by Ezeoha (2007), the banking industry is now confronted with a fundamental business challenges-survival and success in a turbulent environment. As Nigerian banks face further deregulation, increasing competition, and continuously evolving customer demand and expectations, they have to adopt proactive approaches in other to guarantee improved performance. In addition, recent downturn across the globe has created perfect environment for TQM implementation in the Nigerian banking industry. Almost all the companies have been forced to take-up quality improvement projects to make their survival viable in long-term. Even those companies that have not been impacted need to take a fresh look at their processes and prepare themselves for future. So this time, the mandate of quality assurance to customers has been forced on almost all banks, and the top management is not left with any option but to ensure that continuous products quality are maintained in the best interest of the company (Adeyemi and Aremu, 2008).

There has been global phenomenon increase in TQM implementations across all types of firms competing in every imaginable industry in the past decades (Mohrman et al., 1995; Partlow, 1996; Sila and Ebrahimpour, 2003). Many Nigerian banks have adopted TQM as enablers to facilitate related shifts and become more adaptable so as to operate better in such dynamic business environments. However, despite the significant growth of the TQM concept, not all organisations embarking on TQM projects achieve 
their intended result. Mohrman et al. (1995), Partlow (1996) and Sila and Ebrahimpour (2003) estimates that as many as 40 to $60 \%$ do not achieve the results they seek. This is attributed to poor implementation of TQM rather than a problem with the concept itself (Mohrman et al., 1995; Partlow, 1996). The biggest obstacles (critical failure factors CFFs) that TQM implementation faces, according to the Malcolm Baldrige National Quality Award (MBNQA) 2001 framework, are: problems related to human resources focus, leadership, strategic planning, process management, information and analysis, and customer and market focus (Sila and Ebrahimpour, 2003). Even though impressing results have been achieved, the high rate of failure leads to an immense waste of resources in many organisations. This waste might be avoided, if stakeholders would gain genuine knowledge about the concept they are struggling with, and since Nigerian banks are not immune against TQM project failure; therefore, it is highly necessary to direct research efforts toward this area.

The high failure rate confirm the complexities involved in TQM implementation process, hence, the need for a thorough and cohesive insight into the characteristics and dynamics of TQM and their critical success factors (CSFs). This study aims to fulfil this inquiry by developing a framework for TQM implementation in other to uncover the important critical success factors in implementing TQM, as well as, validate empirically, by examining specific relationships between the identified CSFs of TQM and CSM. Since an extensive longitudinal study of the rise and fall of TQM with respect to the relationship-factor of the important variables has hardly been done, in the Nigerian context, this study also intends to bridge the gap. In other word, this study will provide a holistic view of the TQM implementation process, by reviewing the hard and soft factors that cause success, as well as, examine the relationship between successful TQM and CSM in the Nigerian banking industry. Based on the above objectives, the following research questions were formulated:

1 What factors influence the success of TQM implementations in Nigerian banking industry?

2 What relationship exists between human resources focus and CSM in Nigerian banking industry?

3 To what extent is the relationship between leadership and CSM in Nigerian banking industry?

4 What relationship exists between strategic planning and CSM in Nigerian banking industry?

5 To what extent is the relationship between process management and CSM in Nigerian banking industry?

6 What relationship exists between information and analysis and CSM in Nigerian banking industry?

7 To what extent is the relationship between customer and market focus and CSM in Nigerian banking industry?

The above research questions were investigated from a theoretical and empirical perspectives by means of analysing and discussing the existing literature as well as engaging in some in-depth survey of some selected Nigerian banks that have implemented TQM effort in the past one decade. 


\section{Review of relevant literature}

The definitions of both quality and TQM have been debated for many years, although, Feigenbaum (1951) and Abbott (1955) defined quality as 'value', Levitt (1972) as conformance to specifications', Juran et al. (1974) as 'fitness for use', Crosby (1979) as 'conformance to requirements', there is still no universal agreement on these definitions; however, the most widespread definition of quality, in recent time, is the extent to which a product or service meets and/or exceeds a customer's expectations, which reflects a shift in focus to customer satisfaction (Sila and Ebrahimpour, 2003).

Furthermore, as synonymous to the definition of quality, perspectives and views vary as regards the definition of TQM: "TQM is an approach to managing organizations which emphasizes the continuous improvement of quality and customer satisfaction, entails the application of systematic tools and approaches for managing organizational processes with these ends in mind, and involves the establishment of structures such as quality improvement teams and councils for maintaining focus on these ends and enacting organizational improvement processes" [Mohrman et al., (1995), p.26]. In this study, TQM means the organisation's culture and supports for the consistent attainment of customer satisfaction through an integrated system of tools, techniques, and training; hence, it involves the continuous improvement of organisational processes, resulting in high quality products and services' [Sila and Ebrahimpour, (2003), p.237]. According to Sila and Ebrahimpour (2003), both perspectives emphasise similar concepts, include continuous improvement, customer focus, human resource management and process management.

\subsection{Theoretical and empirical frameworks}

TQM can be considered as a combined application of theories and concepts from mainly four areas - organisation theory, marketing, economic and informatics (Sila and Ebrahimpour, 2003). This is due to the fact that much of TQM can be deduced from existing theories within these areas. However, interdepencies are not only found between TQM and each of the theoretical areas, even the source areas are highly interrelated and cannot be considered as single entities, but as a network of theories, together building a theoretical bedrock for the TQM concept (Sila and Ebrahimpour, 2003).

Change management is a structured approach to shifting/transitioning individuals, teams, and organisations from a current state to a desired future state; it is an organisational process aimed at helping employees to accept and embrace changes in their current business environment (Jarrar and Aspinwal, 1999). Hence, an effective change agent must be able to plot where people are on the transition curve, and respond appropriately. In addition, TQM emphasises the decentralisation of decisions within the organisation, i.e., that process managing teams shall take all decisions, directly concerning 'their' process themselves, as long as they are kept within the strategic frame defined by the company's top management. This view is rather congruent with the trend towards decentralisation during the 1980s, when a wave of decentralisation swept over organisations in most branches. Companies were divisionalized and decision power was brought down within the still existing hierarchies (Redding, 2005). TQM focuses on the need of considering customer needs and requirements, as well as on 'value-adding' as the major factors for determining business processes. Adding value for customers is, by all TQM methodologies, considered as being most of the most important contingencies. The 
concept of value adding was originally developed by Porter (1980) and described in his book Competitive Advantage. His publication was therefore used as basis for integrating marketing aspects into the TQM framework.

Under economic perspective, are market power theory, transaction cost economics, increasing returns theory and resource-based theory. The market power theory is concerned with the ways in which firms can improve their competitive success, which is the ultimate goal of TQM, by securing a stronger position in their market (Talwar, 1993). Transaction cost economics holds an assumption that TQM are implemented in order to lower the transaction costs. The resource-based view suggests that valuable firm resources - comprising tangible and intangible elements - are usually scarce, imperfectly imitable, and lacking in direct substitutes; it is about producing the most value from one's existing capabilities and resources by combining these with others' sources of advantage and, in this, ensuring complementarity is paramount (Earl, 1996). However, it can be stated that IT plays a major role in the majority of TQM projects. But, even though information technology can be an enabler, if used innovatively, it must not necessary drive change. As Yates observed when looking on the impact of IT development on organisational change, the period from implementation to change can vary significantly in time (Yates, 1989). Beyond that delay in time, the performed change was often of rather incremental nature. It may be concluded, that IT is only one of an assembly of change enablers, and if used inappropriate, it might even be a disabling factor. Beyond that, technology must be applied in an understandable way when trying to link IT capabilities to organisational objectives desired with the implementation of TQM, as a strategic imperative (Earl, 1996).

Figure 1 Effects of successful TQM implementation efforts on CSM

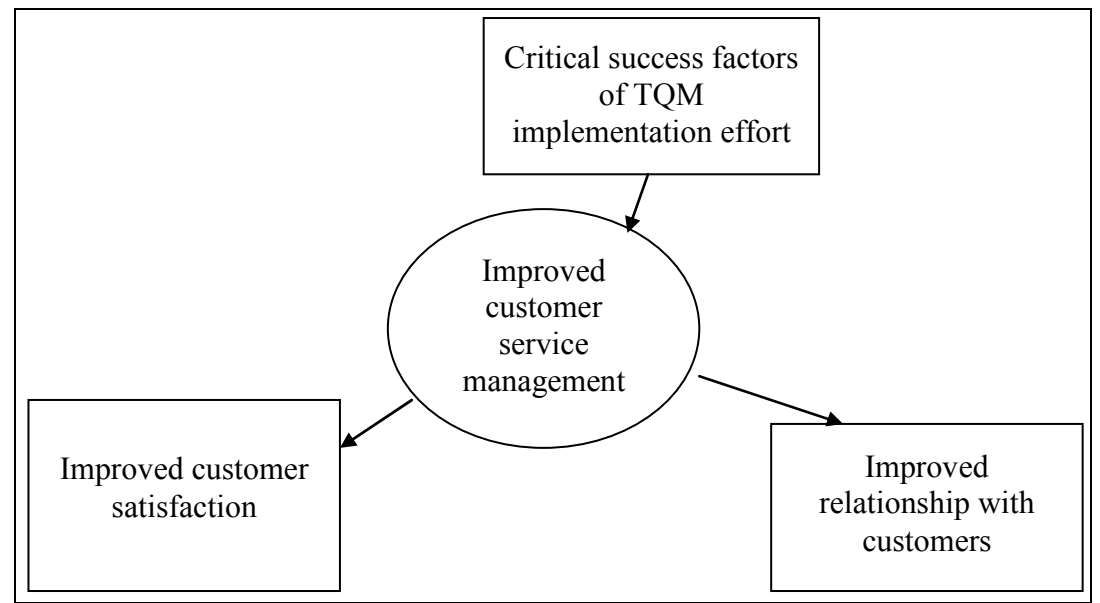

Source: Adapted from Sila and Ebrahimpour (2003)

In this paper, as depicted in Figure 1, an empirical framework was created to assess the effects of the CSFs of TQM on CSM. When the TQM implementation effort is successful, customers are likely to be satisfied with their products or services. Furthermore, customers are also likely to be satisfied with the customer services offered by a company. In both instances, complaints are likely to be lesser. A successful TQM effort can also enable banks to better manage its customer relationship. Given the above 
submissions, it is pervasive that successful TQM efforts should result in positive CSM. Therefore, a successful TQM effort can lead to improved customers' relationship management and satisfaction.

\subsection{CSFs of TQM implementation}

When TQM is properly implemented and assimilated, the incremental benefits accrued can be extremely relevant, leveraging most of the key strategic drivers in organisations (Crosby, 1979; Feigenbaum, 1951; Juran et al., 1974). Case studies have revealed that successful TQM implementations can contribute dramatic cost savings because of underlying quality and process integration, which enables different ways to manage business products and services inducing a positive impact on profits. Other studies have also analysed TQM impact on revenue-creating core processes, such as customer services, sales and distribution, resulting in a strong bottom line (Sila and Ebrahimpour, 2003).

In focusing this study, the factors listed below were distilled from various articles and empirical research on TQM implementation. They were then categorised into a number of subgroups, similar to the MBNQA 2001 framework, representing various dimensions of change related to TQM implementation. These dimensions are as follows, and the related success/failure factors are depicted in Table 1:

1 human resources focus

2 leadership

3 strategic planning

4 process management

5 information and analysis

6 customer and market focus.

Table 1 Critical success/failure factors of TQM

\begin{tabular}{lll}
\hline Variables & Failure factors \\
\hline Human resources focus & \multicolumn{2}{l}{ Problem related to: } \\
1 & Human resource management \\
2 & Workforce commitment to quality \\
3 & Employee involvement \\
4 & Problems related to employee empowerment \\
5 & Lack of training \\
6 & Employee fulfilment \\
7 & Teamwork \\
8 & Employee performance appraisal, rewards and recognition \\
9 & Communication \\
\hline
\end{tabular}

Source: Adapted from Sila and Ebrahimpour (2003), Mohrman et al. (1995), and Partlow (1996) 
Table 1 Critical success/failure factors of TQM (continued)

\begin{tabular}{|c|c|c|}
\hline \multirow{2}{*}{$\begin{array}{l}\text { Variables } \\
\text { Leadership }\end{array}$} & \multicolumn{2}{|c|}{ Failure factors } \\
\hline & 10 & $\begin{array}{l}\text { Problem related to commitment, support and organisational } \\
\text { leadership, commitment and vision in implementing TQM }\end{array}$ \\
\hline & 11 & Problem related to public responsibility and citizenship \\
\hline Strategic planning & 12 & $\begin{array}{l}\text { Poor management of: 'quality strategy', 'strategy and } \\
\text { innovation', 'strategic quality planning', 'strategic integration', } \\
\text { 'policy and strategy', 'strategy for TQM', 'operational quality } \\
\text { planning', 'strategic quality management', 'quality goals and } \\
\text { policy', 'vision', 'vision and plan statement' and 'quality } \\
\text { mission statement' }\end{array}$ \\
\hline \multirow[t]{8}{*}{ Process management } & 13 & Problem related to process control \\
\hline & 14 & Problem related to product, service and/or process design \\
\hline & 15 & Inadequate supplier management \\
\hline & 16 & Ineffective continuous improvement \\
\hline & 17 & Problem related to quality assurance \\
\hline & 18 & Unrealistic cycle time reduction \\
\hline & 19 & Zero defects \\
\hline & 20 & Innovation \\
\hline \multirow{2}{*}{$\begin{array}{l}\text { Information and } \\
\text { analysis }\end{array}$} & 21 & Quality data and reporting \\
\hline & 22 & Benchmarking \\
\hline $\begin{array}{l}\text { Customer and market } \\
\text { focus }\end{array}$ & 23 & $\begin{array}{l}\text { Poor or lack of: 'customer focus', 'customer focus and } \\
\text { satisfaction', 'customer analysis', 'close cooperation with } \\
\text { customers', 'customer service', 'customer orientation', } \\
\text { 'customer satisfaction orientation' and 'customer feedback' }\end{array}$ \\
\hline
\end{tabular}

Figure 2 Relationship between CSFS of TQM and CSM

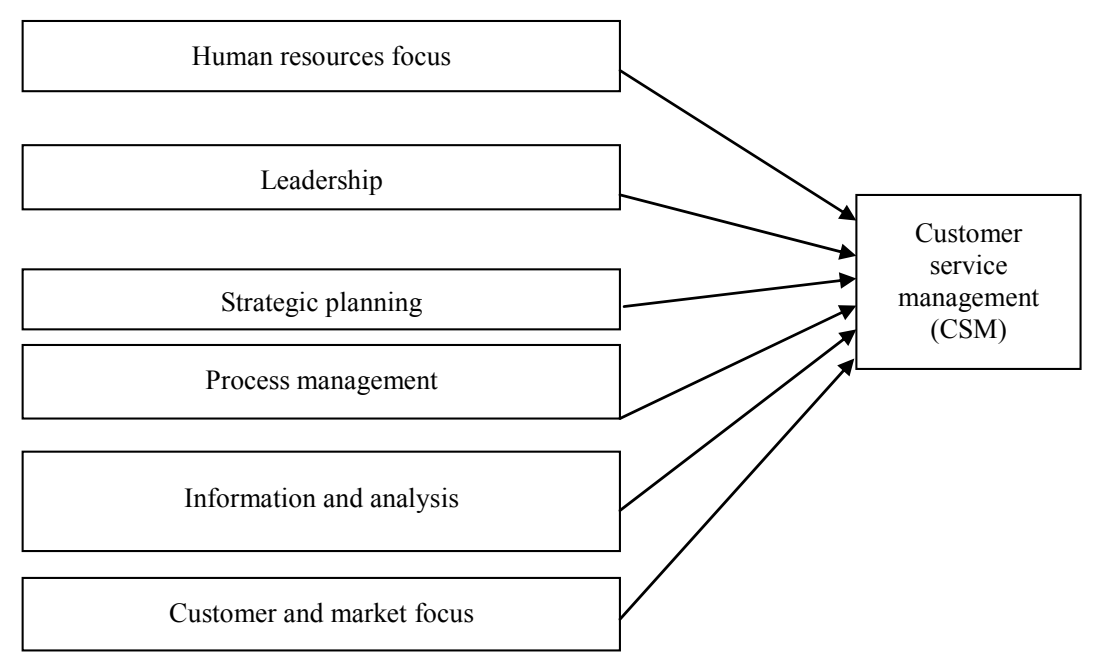


Table 2 The measure of CSFs of TQM

\begin{tabular}{|c|c|}
\hline Variable & Description of factors \\
\hline A1 & $\begin{array}{l}\text { There is acceptable performance appraisal, rewards systems and recognition to } \\
\text { motivate and promote workforce commitment to quality }\end{array}$ \\
\hline A2 & $\begin{array}{l}\text { There is effective communication throughout the TQM process to ensure patience and } \\
\text { understanding of the organisational and cultural changes }\end{array}$ \\
\hline A3 & $\begin{array}{l}\text { Staff set their goals, monitor their own performance, identify and solve problems that } \\
\text { affect their work }\end{array}$ \\
\hline A4 & $\begin{array}{l}\text { Teams and other staff are empowered and actively involved throughout the TQM } \\
\text { stages }\end{array}$ \\
\hline A5 & $\begin{array}{l}\text { Staff is educated and trained in interpersonal, IT and process analysis techniques skills } \\
\text { to endorse successful TQM }\end{array}$ \\
\hline A6 & The enterprise understands and conforms to the newly established culture \\
\hline A7 & The enterprise prepares staff to respond positively to TQM changes \\
\hline B1 & $\begin{array}{l}\text { Leadership is effective, strong, understanding and creative in thinking thus providing } \\
\text { a clear vision for the future }\end{array}$ \\
\hline B2 & $\begin{array}{l}\text { There is commitment and support from the top management throughout the TQM } \\
\text { process }\end{array}$ \\
\hline B3 & $\begin{array}{l}\text { There are TQM champions and leaders who continually push TQM efforts throughout } \\
\text { the enterprise }\end{array}$ \\
\hline B4 & TQM philosophy align with good public responsibility and citizenship \\
\hline $\mathrm{C} 1$ & TQM implementation are constantly review to align with plans and budgets \\
\hline $\mathrm{C} 2$ & $\begin{array}{l}\text { There is a clear and compelling TQM vision that direct both long-term and } \\
\text { day-to-day operations }\end{array}$ \\
\hline $\mathrm{C} 3$ & There is careful alignment of corporate strategy with TQM strategy \\
\hline D1 & There are continuous improvement techniques integrated with process management \\
\hline D2 & There is effective process review and controls to conform with standards \\
\hline D3 & Quality controls and specifications of products/services are strictly maintained \\
\hline D4 & Suppliers and customers are integrated into the value chains and company's database \\
\hline D5 & $\begin{array}{l}\text { Organisations product, service and/or processes are well designed to support TQM } \\
\text { philosophy }\end{array}$ \\
\hline D6 & Innovation and zero defects philosophy are propagated among employees \\
\hline E1 & Quality information and data are readily available in the organisation \\
\hline E2 & $\begin{array}{l}\text { Market research, competitive analysis and benchmarking are used to learn about the } \\
\text { enterprise's customers and competitors }\end{array}$ \\
\hline E3 & $\begin{array}{l}\text { Quality improvement measurement systems and IT infrastructures are install to } \\
\text { generate quality data, information sharing and evaluation }\end{array}$ \\
\hline E4 & $\begin{array}{l}\text { There is alignment of IT infrastructure with TQM strategy to synergise changes } \\
\text { between the two }\end{array}$ \\
\hline E5 & Process quality and costs are constantly being monitored to conform to standard \\
\hline F1 & Value and supply chains are geared towards efficient customer and market penetration \\
\hline $\mathrm{F} 2$ & TQM strategies are constantly align with marketing strategies \\
\hline F3 & Environmental analysis is conducted to focus on customers and societal demands \\
\hline F4 & Competitive analysis are conducted to monitors company's market shares \\
\hline F5 & $\begin{array}{l}\text { Process and quality orientation are geared toward market demands and customer } \\
\text { satisfaction }\end{array}$ \\
\hline
\end{tabular}

Source: Adapted from Sila and Ebrahimpour (2003), Mohrman et al. (1995), and Partlow (1996) 
In summary, the above literature reviews is tabulated in Table 2, depicting the CSFs of TQM. The relationship between the various construct and CSM are depicted in Figure 2.

\subsection{Customer service management}

Customer service management (CSM) is reflected in a way organisations manage their customer services to create value and satisfaction, through fulfilment of customers' needs and wants (Kotler, 2000). Since the survival of an enterprise depends on its customers, customers are the driving force of TQM programmes. The provision of similar products and services by Nigerian banks has intensifies competition in the industry, and as Nigerian customers become increasingly knowledgeable about the availability of many financial products and services, they are more selective in their options; if they are not satisfied with their current banker's products or services, they can easily switch to other bankers, hence customer retention is crucial to the survival of many banks, and this could be achieved through good CSM.

When there is high customer retention rate, it indicates that these retained customers are satisfied with the services offered by the enterprise, and are likely to invite friends and members of their families (Kotler, 2000). An improved CSM can also expedite and enhance customer re-buy, which often resulted to improved customer satisfaction, customer retention and relationship management (Khong, 2005). Therefore, CSM is an important endogenous construct in determining organisation success in TQM efforts. According to the framework of Khong and Mahendiran (2006), the variables manifesting good CSM are depicted in Table 3.

Table 3 The measure of CSM

\begin{tabular}{ll} 
Variable & Key factors manifesting CSM \\
\hline G1 & Market research is conducted to discover what customers expect from the enterprise \\
G2 & Market research is conducted to monitor changes in customer satisfaction \\
G3 & There is a record of customers' requests, complaints and transactions for future \\
& reference \\
G4 & Customers' are requested to provide feedback on the products/ services \\
G5 & Customers' complaints and feedback are used to improve the products/services \\
G6 & There is a review of mistakes (post-mortem) when a customer is lost \\
G7 & Customers are satisfied with the products/services \\
G8 & Customers are satisfied with the customer service \\
G9 & Customers are the most important factor in the organisation \\
G10 & Customers relationship is well managed by the enterprise \\
\hline
\end{tabular}

Source: Khong and Mahendiran (2006) and Khong (2005)

This framework was based on the fact that, an appropriate CSM should constitute important variables, like, market research into consumer behaviour and expectations, customer database and records, complaint and suggestion systems, management of service quality to meet customer expectations, product or service improvements, efficient customer handling, and lost customer analysis (Mohrman et al., 1995; Partlow, 1996). However, since the purpose of this study is to examine the perceived effect of successful TQM on CSM, it is expected that the former (TQM) will positively improve the latter 
(CSM) (Elmuti, 2003; Mohrman et al., 1995; Partlow, 1996). Research survey and methods follows.

\section{Research methodology}

Surveys were the primary source of data collection for this research. As Khong (2005) claims, survey research is an appropriate method to generalise from a sample to a population, allowing in this sense, to establish inferences over the entire population. A self designed questionnaire was administered to both junior and senior staff of the participating banks. The intended junior and senior staff respondents in the participating banks are expected to be knowledgeable of the various constructs in the questionnaire, especially, in relation to TQM and CSM (Khong and Mahendhiran, 2006; Sila and Ebrahimpour, 2003). As used in previous studies, these respondents were chosen based on the premise that they are mostly front office staff, and among the most knowledgeable informants on TQM implementations in their respective organisations (Sila and Ebrahimpour, 2003; Mohrman et al., 1995; Partlow, 1996). From a time dimension, this research adopts a one-time cross-sectional perspective, and the unit of analysis is the firm.

\subsection{Pilot study and test}

During the pilot study, to get insights into the essential CSFs of TQM implementation and its effects on CSM, in the Nigerian context, all items representing the various constructs were validated and accepted individually by three professors in management studies and six experts in TQM implementation, specifically in the Nigerian context. Recommendations from experts were processed after effecting necessary modifications and then, the final version of the instrument was accepted. Two Nigerian banks were investigated at the pilot stage of the research, hence, convenience sampling techniques was deemed desirable. In other word, given the visibility of participating banks and to reduce bias, the two banks at the pilot stage were excluded from the main research. In addition, convenience sample was used because it allowed the researcher to obtain basic data and trends regarding this study without the complications of using a randomised sample (Khong, 2005).

The results of the pilot test was processed and analysed. From the results of the pilot study, the mean Cronbach's alpha of all the six and one constructs measuring CSFs of TQM and CSM yielded 0.90 and 0.92 respectively. This were well above the recommended minimum of 0.70 , hence, the set of variables were consistent in what it is intended to measure (Hair et al., 1998). In addition, a test-retest reliability was conducted within one week interval on the two banks selected at the pilot stage of this study. 160 questionnaires were administered, out of which 95 questionnaires were returned. Thirteen questionnaires were discarded from analysis due to omission of vital variables by respondents. In all 82 (51\% response rate) questionnaires were accepted and analysed at the pilot stage. Finally, the test-retest reliability yielded a Poison moment correlation coefficient of 0.89 , meaning that the instrument was sufficient in its measures. $R^{2}$ generated was 0.6422 or $64.22 \%$, meaning that, the six constructs representing the CSFs of TQM sufficiently explained $64.22 \%$ of the total variation in CSM. 
A multi-stage sampling technique was adopted in the main study. Since Nigeria is made up of six geo-political zones, the first stage involved the use of purposeful and stratified sampling method. For equal representation, a state is expected to be picked randomly from each geo-political zone, hence, Lagos, Delta, Enugu, Sokoto, Kogi and Borno states were selected from south-west, south-south, south-east, north-west, north-central and north-east respectively. Stratification involves the division of Nigerian banks into two: 'national and international bank'. 'National banks' are banks with national licenses, while 'international banks' are banks with international licenses. However, three banks from each namely, First bank of Nig.plc., United bank for Africa, First city monument bank (international bank strata) and IBTC-Chartered Bank plc., Sterling bank, Unity bank plc. (National bank strata) were subsequently selected. The second stage involves the use of proportionate sampling method. These banks are depicted in Table 4, with the allotted questionnaires, based on the total staff strength and the proportion of Junior to senior staff in each selected bank. The last stage involves the use of random sampling method, in selecting the final respondents for each bank, based on the total allotted questionnaires.

Table 4 Participating banks in the survey

\begin{tabular}{|c|c|c|c|}
\hline Name of bank & Consolidating institutions & $\begin{array}{c}\text { Total } \\
\text { questionnaire }\end{array}$ & $\begin{array}{l}\text { Proportion of } \\
\text { sampling unit } \\
\quad \text { (junior: } \\
\text { Senior staff) }\end{array}$ \\
\hline $\begin{array}{l}\text { First city Monument } \\
\text { bank plc. }\end{array}$ & $\begin{array}{l}\text { First City Monument Bank, } \\
\text { Cooperative Development Bank, } \\
\text { and Nig-American Bank }\end{array}$ & 321 & $65: 35$ \\
\hline $\begin{array}{l}\text { First bank of Nigeria } \\
\text { plc. }\end{array}$ & $\begin{array}{c}\text { First Bank plc., MBC International } \\
\text { Bank and FBN (Merchant Banker) } \\
\text { Ltd. }\end{array}$ & 469 & $62: 38$ \\
\hline $\begin{array}{l}\text { IBTC-Chartered Bank } \\
\text { plc. }\end{array}$ & $\begin{array}{c}\text { IBTC, Chartered Bank and Regent } \\
\text { Bank }\end{array}$ & 372 & $64: 36$ \\
\hline Sterling bank & $\begin{array}{c}\text { Trust bank, NBM Bank, Magnum } \\
\text { Bank, NAL Bank and } \\
\text { Indo-Nigerian Bank }\end{array}$ & 266 & $70: 30$ \\
\hline $\begin{array}{l}\text { United bank for Africa } \\
\text { plc. }\end{array}$ & $\begin{array}{l}\text { United Bank for Africa and } \\
\text { Standard Trust Bank }\end{array}$ & 532 & $72: 28$ \\
\hline Unity bank plc. & $\begin{array}{c}\text { Intercity Bank, First Interstate } \\
\text { Bank, Tropical Commercial Bank, } \\
\text { Centre Point Bank, Bank of the } \\
\text { North, New African Bank, Societe } \\
\text { bancaire, Pacific Bank and New } \\
\text { Nigerian Bank }\end{array}$ & 320 & $67: 33$ \\
\hline
\end{tabular}

Source: Ezeoha (2007)

In all, based on the CBN sample frame of employees in Nigerian banks (Sanusi, 2010), the total questionnaire was settled at 2,280 (sampling unit), and same number were delivered to all participating banks, with the assistance of two trained Research Assistants. 
In the questionnaire, participants were asked to answer two important sections; one with regards to the CSFs of TQM and the other to CSM. In CSFs of TQM, they were asked to rate the degree of usefulness of 30 variables (Table 2) in association with their banks' TQM implementation strategies; in CSM, they were also asked to rate ten variables (Table 3 ). Each of the variables contained questions with the rating based on an interval scale from 1 to 5 , where 1 is 'strongly disagree' and 5 is 'strongly agree'. The N/A (not applicable or no comment) option was included, so as not to force the respondents, by restricting them to the available options.

\section{Results and discussion of findings}

To analyse the data collected via the survey instrument, an appropriate statistical procedure was subsequently formulated using the methodologies recommended by Hair et al. (1998). From the formulated methodologies, specific relationship between CSFs of TQM implementation and CSM were established. In sequential order, the recommended methodologies are:

1 reliability and validity analysis

2 factor analysis

3 regression analysis.

\subsection{Reliability analysis}

Reliability analysis is conducted in order to measure the internal consistency of variables, measured by interval scale items, in a summated scale. In this study, the summated scales are CSFs of TQM and CSM (Khong and Mahendiran, 2006). Using the regression tool in SPSS (statistical package for social scientist), the robustness of Kaiser-Meyer-Olkin (KMO) measure of sampling adequacy (0.688); and the Bartlett's test of sphericity $(1,011.222)$ were also used to rejects/accept the fact that the population correlation matrix is an identity matrix (Table 6). To assess internal consistency, Cronbach's alpha, composite reliability and average variance extracted coefficients were used (Hair et al., 1998). The composite reliability and AVE were calculated using Fornell and Larker's (1981) formula.

Table 5 Summary of test result - reliability analysis

\begin{tabular}{lcccc}
\hline Constructs & $\begin{array}{c}\text { Number of } \\
\text { questionnaire } \\
\text { items }\end{array}$ & $\begin{array}{c}\text { Cronbach's } \\
\text { alpha (mean) }\end{array}$ & $\begin{array}{c}\text { Composite } \\
\text { reliability (CR) }\end{array}$ & $\begin{array}{c}\text { Average variance } \\
\text { extracted (AVE) }\end{array}$ \\
\hline Human resources focus & 7 & 0.913 & 0.888 & 0.863 \\
Leadership & 4 & 0.912 & 0.827 & 0.703 \\
Strategic planning & 3 & 0.963 & 0.885 & 0.719 \\
Process management & 6 & 0.897 & 0.809 & 0.711 \\
Information and analysis & 5 & 0.887 & 0.744 & 0.701 \\
Customer and market & 5 & 0.901 & 0.733 & 0.712 \\
focus & 10 & 0.904 & 0.842 & 0.754 \\
CSM & & & & \\
\hline
\end{tabular}


From the results of the reliability analysis, shown in Table 5, the Cronbach's alpha of all the seven constructs measuring successful TQM and CSM are well above the recommended minimum of 0.70 , hence, the set of variables are consistent in what it is intended to measure (Hair et al., 1998). Hence, the internal consistencies of variables, measured by interval scale items, in a summated scale (CSFs of TQM and CSM) are adequate in measuring the various constructs (Khong and Mahendiran, 2006). Furthermore, all the calculated composite reliability scores were above the recommended 0.7 , hence, the overall reliability of the whole scale (composite reliability) is assured (Hair et al., 1998). Lastly, all the calculated AVE were also well above 0.5 (Hair et al., 1998), hence, the internal consistency of the constructs are guaranteed.

\subsubsection{Test result for validity analysis}

Different validity terms were used to demonstrate various aspects of construct validity. This research utilised convergent and discriminant validity to indicate the ability of the measurement items to measure accurately the constructs of the study (Hair et al., 1998). Convergent validity is recognised when the relationship between measurement items and the factor is significantly different from zero.

Table 6 Summary of test result - validity analysis and KMO and Bartlett's test

\begin{tabular}{|c|c|c|c|}
\hline \multirow{2}{*}{ Model } & \multicolumn{2}{|c|}{ Collinearity statistics } & \\
\hline & $V I F$ & Tolerance & \\
\hline \multicolumn{4}{|l|}{ (Constant) } \\
\hline & & & Durbin-Watson: \\
\hline Human resources focus & 1.081 & .981 & \\
\hline Leadership & 1.117 & .973 & \\
\hline Strategic planning & 1.105 & .986 & \\
\hline Process management & 1.058 & .924 & \\
\hline Information and analysis & 1.035 & .954 & \\
\hline Customer and market & & & 2.444 \\
\hline Focus & 1.026 & .911 & \\
\hline \multicolumn{4}{|c|}{ Kaiser-Meyer-Olkin measure of sampling adequacy } \\
\hline & & & 688 \\
\hline \multirow[t]{4}{*}{ Bartlett's test of sphericity } & \multirow{2}{*}{\multicolumn{2}{|c|}{ Approx. chi-square }} & \\
\hline & & & $1,011.222$ \\
\hline & \multicolumn{2}{|l|}{ Df } & 435 \\
\hline & \multicolumn{2}{|l|}{ Sig. } & .000 \\
\hline
\end{tabular}

Factor analysis, via 'Principal Components extraction', was the technique used to test discriminant validity of this study. Factoring method used was 'Principal Components', applying an orthogonal varimax rotation with Kaiser's normalisation (Khong, 2005). Based on these conditions, seven factors were obtained (Kaiser's criterion of retaining factors with eigenvalues greater than 1), which was consistent with the seven variables used in the model. Since AVEs above 0.5 are treated as indications of convergent validity, Khong (2005) posits that, a variance extracted of greater than 0.50 indicates that 
the validity of both the construct and the individual variables is high; indicating that each construct was a distinct construct. In addition, the results of external validity tests are shown in Table 6. Tolerance and VIF coefficients are also within the acceptable range (Hair et al., 1998) to maintain that there is no evident multi-collinearity problem. The assumption of independent errors was tested with the Durbin-Watson, which monitors for serial correlations between errors. A value of 2.444 complies with the assumption of no independent errors, since, a value less than 1 or greater than 3 are definitely cause for concern (Asteriou and Hall, 2007).

\subsection{Factor analysis}

This analysis is used to reduce numerous variables to a more manageable set of factors; hence, the purpose of factor analysis, in this study, was to reduce the 40 variables, of which 30 were manifesting successful TQM and ten manifesting CSM, to a more manageable set of factors (Aaker and Day, 1986). Exploratory factor analysis was used to summarise and reduce the data. After exploratory factor analysis, confirmatory factor analysis (CFA) was also conducted. In order to define which factors determine the successful TQM implementation and CSM efforts, CFA method was employed. When conducting CFA, variables are assigned to specified factors. It is common that variables with high factor loadings will be assigned to describe the respective factors. Therefore, variables that have low loadings on respective factors are constrained to zero (Hair et al., 1998). According to Carmines and Zeller (1979), the acceptable threshold for factor loading is 0.7 or above. Consequently, variables with loadings less than 0.7 were constrained to zero. Using SPSS 15.0, the results of this factor analysis, with the assumption of extracting via principal components method and rotating via varimax, are shown in Table 7.

The factor matrix for successful TQM and CSM revealed seven significant factors, that is, factors $1,2,3,4,5,6$ and 7 respectively; and the seven factors were extracted. Consequently, factors 1, 3, 4, 5, 6 and 7 will manifest the constructs of successful TQM while factor 2 will manifest CSM. From Table 7, variables A1, A2, A3, A4; B2, B4; C1, C2, C3; D1, D2; E2, E3; F2, F5; and G1, G7, G8, G10 were retained for manifesting successful TQM and CSM respectively, because their factor loadings were above the 0.7 threshold. The retained variables were used in estimating a model via regression analysis.

Table 7 Rotated factor matrix

\begin{tabular}{|c|c|c|c|c|c|c|c|}
\hline \multirow{2}{*}{ Variable } & \multicolumn{7}{|c|}{ Factor } \\
\hline & 1 & 2 & 3 & 4 & 5 & 6 & 7 \\
\hline A3 & .836 & & & & & & \\
\hline A 2 & .832 & & & & & & \\
\hline A4 & .768 & & & & & & \\
\hline A1 & .765 & & & & & & \\
\hline \multicolumn{8}{|l|}{$\mathrm{G} 2$} \\
\hline F1 & & & & & & & \\
\hline
\end{tabular}

Notes: Extraction method: principal component analysis (seven components extracted); rotation method: varimax with Kaiser normalisation. 
The effects of total quality management on customer service management

Table 7 Rotated factor matrix (continued)

\begin{tabular}{|c|c|c|c|c|c|c|c|}
\hline \multirow{2}{*}{ Variable } & \multicolumn{7}{|c|}{ Factor } \\
\hline & 1 & 2 & 3 & 4 & 5 & 6 & 7 \\
\hline G7 & & .823 & & & & & \\
\hline G8 & & .805 & & & & & \\
\hline G1 & & .769 & & & & & \\
\hline G10 & & .715 & & & & & \\
\hline G9 & & & & & & & \\
\hline G5 & & & & & & & \\
\hline G3 & & & & & & & \\
\hline G4 & & & & & & & \\
\hline A5 & & & & & & & \\
\hline G6 & & & & & & & \\
\hline E5 & & & & & & & \\
\hline E4 & & & & & & & \\
\hline D3 & & & & & & & \\
\hline E3 & & & .852 & & & & \\
\hline E2 & & & .749 & & & & \\
\hline F3 & & & & & & & \\
\hline E1 & & & & & & & \\
\hline $\mathrm{F} 4$ & & & & & & & \\
\hline A6 & & & & & & & \\
\hline D6 & & & & & & & \\
\hline B2 & & & & .830 & & & \\
\hline B4 & & & & .793 & & & \\
\hline B1 & & & & & & & \\
\hline B3 & & & & & & & \\
\hline B4 & & & & & & & \\
\hline $\mathrm{C} 3$ & & & & & .896 & & \\
\hline $\mathrm{C} 2$ & & & & & .871 & & \\
\hline $\mathrm{C} 1$ & & & & & .814 & & \\
\hline A7 & & & & & & & \\
\hline D2 & & & & & & .817 & \\
\hline D1 & & & & & & .788 & \\
\hline D4 & & & & & & & \\
\hline $\mathrm{F} 2$ & & & & & & & .811 \\
\hline F5 & & & & & & & .776 \\
\hline
\end{tabular}

Notes: Extraction method: principal component analysis (seven components extracted); rotation method: varimax with Kaiser normalisation. 


\subsection{Regression analysis}

After performing factor analysis, regression analysis is a suitable path for analysis; in this study, the underlying hypotheses were analysed using regression analysis. According to Hair et al. (1998), multiple regression analysis is a convenient statistical technique to be used when the researcher requires analysing the relationship between a single dependent variable and several independent variables.

\subsection{Hypothesis testing}

In order to examine the relationships between CSFs of TQM (exogenous constructs) and CSM of Nigerian banks (endogenous constructs), the following hypotheses were tested:

$\mathrm{H}_{0} \quad$ The respective exogenous construct has no positive effects on the respective endogenous construct.

$\mathrm{H}_{1} \quad$ Human resources focus has positive relationship with CSM.

$\mathrm{H}_{2} \quad$ Leadership has positive relationship with CSM.

$\mathrm{H}_{3} \quad$ Strategic planning has positive relationship with CSM.

$\mathrm{H}_{4} \quad$ Process management has positive relationship with CSM.

$\mathrm{H}_{5}$ Information and analysis has positive relationship with CSM.

$\mathrm{H}_{6}$ Customer and market focus has positive relationship with CSM.

$\mathrm{H}_{1}, \mathrm{H}_{2}, \mathrm{H}_{3}, \mathrm{H}_{4}, \mathrm{H}_{5}$ and $\mathrm{H}_{6}$ were set to examine the effects of TQM on CSM. Failure to accept the null indicates that the alternatives are accepted. By testing these hypotheses, an overview of successful TQM towards improved CSM in Nigerian banks can be determined.

Table 8 Testing the hypotheses

\begin{tabular}{|c|c|c|c|c|c|c|}
\hline \multirow{2}{*}{\multicolumn{6}{|c|}{$\begin{array}{l}R^{2}=0.6666 \\
\text { Durbin Watson }=2.444\end{array}$}} & \multirow{3}{*}{$\begin{array}{c}\text { Sig }<.0001 \\
C S M \\
\text { Validation }\end{array}$} \\
\hline & & & & & & \\
\hline $\begin{array}{l}\text { Construct } \\
\text { association }\end{array}$ & ' $\alpha$ ' level & Beta & $\rho$-value & $\begin{array}{l}\text { Significant } \\
\text { (yes/no) }\end{array}$ & Hypothesis & \\
\hline $\begin{array}{l}\text { Human resources } \\
\text { focus with CSM }\end{array}$ & 0.05 & 0.37 & 0.0001 & Yes & Accept H1 & Yes \\
\hline $\begin{array}{l}\text { Leadership with } \\
\text { CSM }\end{array}$ & 0.05 & 0.34 & 0.0411 & Yes & Accept H1 & Yes \\
\hline $\begin{array}{l}\text { Strategic planning } \\
\text { with CSM }\end{array}$ & 0.10 & 0.25 & 0.0507 & Yes & Accept H1 & Yes \\
\hline $\begin{array}{l}\text { Process management } \\
\text { with CSM }\end{array}$ & 0.05 & 0.31 & 0.0277 & Yes & Accept H1 & Yes \\
\hline $\begin{array}{l}\text { Information and } \\
\text { analysis with CSM }\end{array}$ & 0.10 & 0.12 & 0.1502 & No & Accept H0 & No \\
\hline $\begin{array}{l}\text { Customer and market } \\
\text { focus with CSM }\end{array}$ & 0.05 & 0.35 & 0.0311 & Yes & Accept H1 & Yes \\
\hline
\end{tabular}

Note: $\alpha$ level denotes significant level. 


\subsection{Discussion of findings}

Findings based on the survey revealed that successful TQM can positively affect CSM. Except for information and analysis $(\beta=0.12, p=0.1502)$, the results suggests the positive effects of the CSFs of TQM (human resources focus $-\beta=0.37, p=0.0001$; leadership $-\beta=0.34, p=0.0411$; strategic planning $-\beta=0.25, p=0.0507$; process management $-\beta=0.31, p=0.0277$; customer and market focus $-\beta=0.35, p=0.0311$ ) on improved CSM in Nigerian banks, and were corroborated empirically in this study. Strategic planning was validated at $\alpha=0.10$ level of significance. The inability to corroborate information and analysis in this study might be due to low IT enabled services and penetration in Nigerian banks at the period of this study (Ezeoha, 2007). A positive and significant relationship obtained in this study agrees with the findings of Agus (2001), Agus et al. (2000), Sila and Ebrahimpour (2003) and Mohrman et al. (1995). However, not all of the manifesting variables in successful TQM were positively affecting CSM in Nigerian banks; referring to Table 7, variables A5, A6, A7, B1, B3, D3, D4, D5, D6, E1, E4, E5, F1, F3, and F4 were omitted from further analyses due to the setting of 0.7 threshold. In short, based on the dataset, there was insufficient evidence that these 15 variables had statistically significant effect on CSM; therefore, the factor should maintain the fundamental nature of successful TQM.

However, the remaining 15 variables manifesting successful TQM were subsequently ranked according to their importance in the construct. Hence, implementations of effective TQM to improve CSM in the Nigerian banking industry should begin with A3, A2, B2, C3, C2, C1, D2, E3, F2 (park 1) and A4, A1, B4, D1, E2, F5 (park 2). Park 1 variables were the most influential in carrying out successful TQM effort in the Nigerian banking industry. Hence, for TQM implementation to be successful in the Nigerian banking industry, staff must be allowed to set their goals, monitor their own performance, identify and solve problems that affect their work. There must be effective communication throughout the TQM process to ensure patience and understanding of the organisational and cultural changes, commitment and support from the top management throughout the TQM process are also essential. Furthermore, careful alignment of corporate strategy with TQM strategy, as well as, clear and compelling TQM vision that direct both long-term and day-to-day operations is also paramount. TQM implementation must also be constantly reviewed to align with plans and budgets, while effective process review and controls to conform to set standards are also essential. Lastly, quality improvement measurement systems and IT infrastructures must be install to generate quality data, information sharing and evaluation, and most significantly, TQM strategies must be constantly align with marketing strategies of the organisation to achieve successful TQM implementation.

Other secondary prerequisite of a successful TQM effort are: teams and other staff must be empowered and actively involved throughout the TQM stages; acceptable performance appraisal, rewards systems and recognition to motivate and promote workforce commitment to quality; alignment of TQM philosophy with good public responsibility and citizenship; continuous improvement techniques integrated with process management; market research, competitive analysis and benchmarking are used to learn about the enterprise's customers and competitors; and lastly, process and quality orientation geared toward market demands and customer satisfaction. Testing the model fit, the $R^{2}$ coefficient $=0.6666$, implying that the six independent variables explain 
$66.66 \%$ of the variance of CSM. In summary, it is pervasive that successful TQM should result in positive CSM, hence, a successful TQM effort can lead to improved CSM.

\subsubsection{Model fit}

The final step in factor analysis involves the determination of model fit. After conducting the validity and reliability tests for all of the CSF of TQM, it is also necessary to demonstrate the overall fit of the measurement model. The overall fit of the measurement model was determined by CFA. The fit of this model was extremely important in that all possible factors were nested appropriately within it (Ho, 2000). To evaluate the measurement model in this study, a variety (multiple criteria) of 'goodness of fit' indices were used (Byrne, 2001): the normed $X^{2}$ or $X^{2} / \mathrm{df}$ ratio, the root mean square error of approximation (RMSEA), the comparative fit index (CFI), Tucker-Lewis Index (TLI), normed fit index (NFI), incremental fit index (IFI), and the relative fit index (RFI) (Hair et al., 1995; Schumacker and Lomax, 1996; Byrne, 2001; Holmes-Smith, 2001). Table 8 shows the acceptable fit criteria and the CSM fit indices values. All of the statistical values of the final measurement model indicated that the model fitted well in representing the data.

Table 9 Goodness of fit indices for the CSM model

\begin{tabular}{lcc}
\hline Goodness of fit indices & Fit criteria & CSM model \\
\hline$X^{2}$ & & $1,011.222$ \\
$\mathrm{df}$ & $=3$ & 435 \\
$X^{2} / \mathrm{df}$ & $=0.08$ & 2.325 \\
RMSEA & $=0.9$ & 0.061 \\
CFI & $=0.9$ & 0.96 \\
TLI & $=0.9$ & 0.95 \\
NFI & $=0.9$ & 0.95 \\
IFI & $=0.9$ & 0.95 \\
RFI & & 0.96 \\
\hline
\end{tabular}

Source: Adapted from Hair et al. (1995), Schumacker and Lomax (1996), Byrne (2001), and Holmes-Smith (2001)

\section{Conclusions and implications for practice}

In this paper, an empirical framework was created to assess specific relationships between the CSFs of TQM and CSM in the Nigerian banking industry. This paper posit that for TQM implementation to be successful in the Nigerian banking industry, Staff must be allowed to set their goals, monitor their own performance, identify and solve problems that affect their work. There must be effective communication throughout the TQM process to ensure patience and understanding of the organisational and cultural changes, commitment and support from the top management throughout the TQM process are also essential. Furthermore, careful alignment of corporate strategy with TQM strategy, as well as, clear and compelling TQM vision that direct both long-term and day-to-day operations is also paramount. TQM implementation must also be 
constantly reviewed to align with plans and budgets, while effective process review and controls to conform to set standards are also essential. Lastly, quality improvement measurement systems and IT infrastructures must be install to generate quality data, information sharing and evaluation, and most significantly, TQM strategies must be constantly align with marketing strategies of the organisation to achieve successful TQM implementation.

The paper also associated the effects of successful TQM effort to improved CSM. As a result, the measurement and structural equation contrived offered a mathematical interpretation of how TQM implementation can affect CSM. Hence, to enhance their competitive position, Nigerian banks should give high priority to their TQM efforts. This equation is expected to be used by banks in composing strategies to optimise their management of TQM efforts and CSM. The model provides predictive implications on improved CSM, given the activities of critical factors manifesting successful TQM. This research can help in demonstrating how some CSFs of TQM implementations can determine CSM implementation success, stimulating Nigerian banks to embrace TQM efforts that can impact their competitiveness. Moreover, the corroborated findings provide valuable implications for practice. Finally, this study is expected to provide specific direction to companies contemplating a TQM programme, hence, the study is expected to be beneficial to Nigerian banks and other Nigerian companies alike, policy makers in private and public sectors of the Nigerian economy by, enabling better strategic and tactical judgements with regards to TQM implementations. It will help Nigerian banks understand TQM as a business philosophy, its key components and benefits. It will also explore imperatives for successful implementation. It will serve as a veritable source of information for decision makers who need to commit resources to such a venture, project team members and consultants who seek to avoid implementation pitfalls, as well as, professionals who work in this and other related fields.

However, since only one perspective in each organisation was collected - junior and senior staff responsible/actively participated in the TQM implementation process; and for the fact that few respondents were chosen from each participant banks, it is not unreasonable to claim that a method bias may limit the research findings. But even if the constructs measured were conceived as 'perceptual' ones identified by a rater (junior and senior staff), additional guidelines might be used in future studies to minimise this potential limitation, including:

a to use different methods to measure the independent versus dependent variables

b to call for multiple raters from different rater classes, such as management staff, consultants and end-users/customers.

\section{References}

Aaker, D.A. and Day, G.S. (1986) Marketing Research, 3rd ed., pp.443-453, John Wiley \& Sons, New York, NY.

Abbott, L. (1955) Quality and Competition, Columbia University Press, New York.

Adeyemi, S. and Aremu, M.A. (2008) 'Impact assessment of business process reengineering on organizational performance', European Journal of Social Sciences, Vol. 7, No. 1, pp.115-125.

Agus, A. (2001) 'A linear structural modeling of total quality management practices in manufacturing companies in Malaysia', Total Quality Management, Vol. 12, No. 5, pp.561-573. 
Agus, A., Kumar, S., Latifah, S. and Kadir, S.A. (2000) 'The structural impact of total quality management on financial performance relative to competitors through customer satisfaction: a study of Malaysian manufacturing companies', Total Quality Management, Vol. 11, Nos. 4-6, pp.814-826.

Asteriou, D. and Hall, S.G. (2007) Applied Econometrics: A Modern Approach, Revised ed., Palmgrave Macmillan, NY.

Byrne, B. (2001) Structural Equation Modelling with AMOS, Lawrence Erlbaum Associate, New Jersey.

Carmines, E.G. and Zeller, R.A. (1979) Reliability and Validity Assessment, pp.59-70, Sage Publications, Thousand Oaks, CA.

Crosby, P.B. (1979) Quality is Free: The Art of Making Quality Certain, New American Library, New York.

Davenport, T.H. and Short, J.E. (1990) 'The new industrial engineering: information technology and business process redesign', Sloan Management Review, Vol. 3, No. 2, pp.11-27.

Earl, M. (1996) 'The risk of outsourcing IT', Sloan Management Review, Vol. 3, No. 2, pp.26-32.

Elmuti, D. (2003) 'The perceived impact of outsourcing on organisational performance', Mid-American Journal of Business, Vol. 18, No. 2, pp.33-37.

Ezeoha, A. (2007) 'Structural effects of banking industry consolidation in Nigeria: a review', Journal of Banking Regulation, Vol. 8, No. 2, pp.159-178.

Feigenbaum, A.V. (1951) Quality Control: Principles, Practice, and Administration, McGraw-Hill, New York.

Fornell, C. and Larker, D. (1981) 'Evaluating structural equation models with unobserved variables and measurement errors', Journal of Research Marketing, Vol. 27, No. 3, pp.445-466.

Hair, J., Anderson, R., Tatham, R. and Black, W. (1995) Multivariate Data Analysis with Readings, Prentice-Hall International, Englewood Cliffs.

Hair, J.F., Anderson, R.E., Tatham, R.L. and Black, W.C. (1998) Multivariate Analysis, 5th ed., Prentice-Hall, Englewood Cliffs, NJ.

Ho, R. (2000) Handbook of Univariate \& Multivariate Data Analysis \& Interpretation: SPSS Approach, Central Queensland University, Rockhampton.

Holmes-Smith, P. (2001) Introduction to Structural Equation Modelling Using LISREAL, ACSPRI-Winter training Program, Perth.

Jarrar, Y.F. and Aspinwall, E.M. (1999) 'Business process re-engineering: learning from organizational experience', Total Quality Management, Vol. 10, No. 2, pp.173-186.

Juran, J.M., Gryna, F.M. and Bingham, R.S. (1974) Quality Control Handbook, McGraw-Hill, New York.

Khong, K.W. (2005) 'The perceived impact of successful outsourcing on customer service management', Supply Chain Management: An International Journal, Vol. 10, No. 5, pp.402-411.

Khong, K.W. and Mahendiran, N. (2006) 'The effects of customer service management on business performance in Malaysian banking industry: an empirical analysis', Asia Pacific Journal of Marketing and Logistics, Vol. 18, No. 2, pp.111-128.

Kotler, P. (2000) Marketing Management, 10th ed., Prentice Hall, Englewood Cliffs, NJ.

Levitt, T. (1972) 'Production-line approach to service', Harvard Business Review, Vol. 50, No. 4, pp.41-52.

Mohrman, S.A., Tenkasi, R.V., Lawler, E.E. and Ledford, G.E. (1995) 'Total quality management: practice and outcomes in the largest US firms', Employee Relations, Vol. 17, No. 2, pp.26-41.

Partlow, C.G. (1996) 'Human-resources practices of TQM hotels', Cornell Hotel and Restaurant Administration Quarterly, October, Vol. 3, No. 4, pp.67-77.

Porter, M.E. (1980) Competitive Strategy: Technique for Analyzing Industries and Competitors, Free Press, New York. 
Redding, G. (2005) 'The thick description and comparison of societal systems of capitalism', Journal of International Business Studies, Vol. 36, No. 2, pp.123-155.

Sanusi, L.S. (2010) 'Consolidation in the Nigerian banking industry - the journey so far', Thisday Newspaper, 25 August.

Schumacker, R. and Lomax, R. (1996) A Beginner Guide to Structural Equation Modelling, Lawrence Erlbaum Association, Mahwah, New Jersey.

Sila, I. and Ebrahimpour, M. (2003) 'Examination and comparison of the critical factors of total quality management (TQM) across countries', International Journal of Production Research, Vol. 41, No. 2, pp.235-268.

Talwar, R. (1993) 'Business re-engineering \pm a strategy-driven approach', Long Range Planning, Vol. 26, No. 6, pp.22-40.

Yates, J. (1989) Control Through Communication: The Rise of System in American Management, The John Hopkins University Press, Baltimore. 